few hard fæces, which I thought (from his passing so small a portion of the enema) must have been lying below the seat of injury. The morphia was continued. In the evening there was considerable pain, but no further motion by the bowel; a considerable amount of urine was passed. The tongue was still dry. I ordered elixir of cascara sagrada, two drachms, to be repeated in four hours. On June 27 th no motion had been passed during the night, but much urine. The tongue was still dry and the pulse, temperature, and condition were generally about the same as they had been on the previous morning. The fulness at the inner side of the femoral vessels had disappeared and the pain at that part was not so severe. I considered that the hernia had been reduced and that there was probably stricture of the gut in the region injured. I again gave an enema of a gallon, rolled the patient gently from side to side of the bed, and kneaded the abdomen. The combined efforts induced considerable peristaltic action, with much pain and desire to defecate, with the result that there was a free motion of the bowels with plenty of fæces. On June 28th the patient was generally better the bowels had been moved once freely during the night, but there was still some abdominal distress. On the 29 th and 30 th he was better, and on July 1st he went out for a walk. The diet throughout consisted of well-boiled gruel, beef-tea, and milk.

Polpier, Mevagissey, Cornwall.

CASE OF CHRONIC NEPHRITIS IN WHICH THE SEVERE DROPSY DISAPPEARED AFTER PERSISTING FOR NEARLY TWELVE MONTHS.

By MatThew Shirley, L.R.C.P. Edin., L.F.P.\&S. Glasg. MEDICAL OFFICER TO THE HUNSLET UNION WORKHOUSE.

A MAN aged thirty-two years was in the Skipton Union Workhouse in November, 1893, and onwards for thirteen weeks under Dr. Wylie and Mr. Welsh. He was swollen to the waist from below upwards and his urine on boiling was nearly solid with albumin. In March, 1894, he was under Mr. Atkinson of Romaldkirk, near Barnard Castle. On Sept. 19th his condition was rather worse and he went to the General Infirmary, Leeds. His urine was examined then, but his condition did not improve. On the 20th he came into the Union Workhouse at Hunslet, when his condition was as follows. There was anasarca from head to foot; the urine on boiling became solid; the patient was very restless; he had a dry, hacking cough ; and was sleepless and muttering. Pilocarpine was given. On Oct. 4th there was no change for the better. The patient had been sweating, was still swollen, and very restless. The pilocarpine was given up. On the 11th the anasarca had become somewhat less. He was more cheerful and felt better. The urine was in the same condition and there were casts. On the 14th the anasarca was less all over and the urine was the same. On the 15th there was no albumin on boiling, but about one-fifth albumin on settling after adding nitric acid. The anasarca was quite gone and the improvement continued. On the $25 \mathrm{th}$ the patient was up and partook of eggs, liquor carnis, a mutton chop, and some milk. He was cheerful, and there was no return of any symptom. There were no casts and the albumin was lessening.

\section{A NOTE ON FIFTY CASES OF INFLUENZA.}

BY H. W. WEBBER, M.S., M.D. LOND.

SEVERAL interesting points with regard to the symptoms and complications occurring in influenza have at times been raised by correspondents of THE LANCET, notably(1) throat affections, (2) the presence of skin eruptions, and (3) the treatment of the disease. My experience in fifty consecutive cases of influenza observed during the last epidemic is that throat trouble has been present in the majority, although the subjective symptoms of this have been slight, no pain on swallowing (or very little) being complained of. On examination the fauces, nvula, sott palate, and pharynz showed a general redness of peculiar dusky colour and dry appearance; the intensity of the inflammation has been fairly proportionate to the degree of pyrexia, though its slow subsidence has been in marked contrast to the usually rapid (from twenty-four to forty-eight hours) fall of temperature. I have not observed swelling of the tonsils beyond a slight congestion accompanying the above condition in any case. In twenty-two of the cases redness of the skin was present. This was of the nature of a congestive erythema, well-marked when pyrexia was at its height and then of deep-red colour, the skin being burning hot to the touch, this disappearing with the fall of temperature and leaving the patient anæmic. In nearly all the cases it was most intense on the face, arms, and hands. No desquamation of any sort has followed in any case. In four of the cases I have observed vesicular herpes; in three this made its appearance on the fall of temperature, in the fourth the patient when first seen was still going about, having a temperature of $102.2^{\circ} \mathrm{F}$. on the fourth day of the disease. In one case the eruption was profuse, involving the alæ and columna nasi and both lips; in the other three a crop of vesicles about the size of a sixpence was situated on the lower lip. My treatment with all has been-(a) during the acute stage confinement to bed, liquid diet, and a mixture of salicylate of soda, bicarbonate of potash, and liquor ammoniæ acetatis, with the addition of a little sal volatile; the latter counteracts the depressing tendency of the salicylate of soda and the influenza virus and seems to lessen the headache, and this, when persisting after the acute stage, I have always found relieved by five-grain doses of antipyrin given every four hours if required; $(b)$ after the subsidence of pyrexia by quinine with strychnia; and (c) special complications, such as broncbial catarrh, which has been frequent, require suitable treatment.

Plymouth.

\section{d attirror}

\section{H O S P T A L P R C TICE, BRITISH AND FOREIGN.} Nulla autem est alia pro certo noscendi via, nisi quamplurimas et mor-
borum et dissectionum historias, tum aliorum tum proprias collectas habere, et inter se comparare.-MorgaGNI De Sed. et Caus. Morb., lib. iv. Procmium.

\section{THE ROYAL EYE HOSPITAL, SOUTHWARK.}

\section{A CASE OF DIPHTHERITIC CONJUNCTIVITIS.} (Under the care of Dr. W. J. Colcisys.)

THE following notes of a case occurring in Dr. Collins's practice at the Royal Eye Hospital, Southwark, deserve record as showing very compietely how the local, constitutional, and bacteriological phenomena which we recognise as diphtheritic have their exact counterpart when the seat of the initial lesion is the conjunctival mucous membrane instead of the faucial. The disease is said to be most common in Germany, but we sometimes get very severe cases in this country as evidenced by the record of this one. We are indebted to Dr. J.W.H. Eyre, clinical assistant, for the notes and the account of the bacteriological investigation.

The patient was a male child aged two years and was first seen by Dr. W. J. Collins on Feb. 10th, 1896. The history given by the mother was that the child's left eye had begun to be inflamed three days previously. The right eye became affected the next day, but it was not until the day previously to her visit to the hospital that the lids had swollen to any extent. When first seen both eyes were affected, the lids being swollen, red, and painful, and difficult to separate on account of the brawny infiltration of the surrounding subcutaneous tissues. On separating the lids by means of retractors the ocular conjunctiva was found to be injected and much chemosed; the palpebral portion was congested and thickened and presented patches of pale greyish-yellow membranous exudation, giving one the impression that a strong caustic had been recently applied. This membrane stripped off easily, leaving a raw bleeding surface below. The corneæ were slightly hazy, but the surface epithelium remained unbroken. A thin milky-white discharge, slight in quantity, exuded from 
the palpebral fissures, excoriating the skin of the cheek. Such was the local condition; added to this the child was obviously ill, being flushed, restless, and irritable, with a temperature of $102^{\circ} \mathrm{F}$. and a pulse of 100 ; he had albuminous urine. No throat symptoms were present, nor could any history of exposure to contagion be elicited. The treatment adopted was the isolation of the child and the use of a lotion of hydrochlorate of quinine (five grains to the ounce) every half hour, an ointment of boracic acid being subsequently applied to the edges of the lids. Once a day the membrane was stripped off and the whole of the palpebral conjunctiva painted with a solution of silver nitrate (twenty grains to the ounce). The membrane at the commencement of the treatment re-formed in the course of a few hours, but after the first day or two the exudation process was much less rapid and entirely ceased in seven days. As the cornea remained a little hazy drops of sulphate of atropia (two grains to the ounce) were instilled from Feb. 17th to 24th. At the end of this period the cornea and conjunctiva had regained their normal appearance. One month later the child was again examined, when there was found to be marked paresis of the extensor muscles of the left hand and forearm. The mother stated that the condition had been more marked a week or so before and was then improving.

Bacterio'ogical examination. - When the child was first seen (Feb. 10th) cover-slip preparations made directly from the serous discharge revealed the presence of numerous poly. nuclear leucocytes, some staphylococci, and slender bacilli. Tnese last measured about $1.75 \mu$ in length, and from the irregular manner in which they took the stain (carbolic methylene blue) presented a somewhat beaded appearance. None were clubbed, and morphologically the bacilli might equally well have been either the bacillus diphtheriæ or the xerosis bacillus. A blood serum tube was theref re inoculated with some of the discharge taken from the left lower conjunctival fornix and incubated at $37^{\circ} \mathrm{C}$. for eighteen hours. At the end of that period the resulting growth consisted of small raised circular or rather spherical colonies of an opaque white colour, which microscopically consisted entirely of what appeared to be the long variety of the Klebs-Löfler bacillus. Some larger colonies of staphylococci were also present From this first culture agar plates were made and the bacillus diphtheriæ was isolated. A subculture in bouillon. was next prepared and after forty. eight hours' incubation at $37^{\circ} \mathrm{C}$. examined and found to be pure. One c.c. was then inoculated into the subcutaneous tissue of the abdomen of a guinea-pig weighing 250 grammes (Feb. 18th) ; eighty-three hours later (the $22 \mathrm{nd}$ ) the guineapig was dead, and post mortem the local oedema and serous effusions usually associated with death resulting from inoculation of the bacillus diphtheriæ were observed. Cover-slip preparations were made and blood serum tubes inoculated with the conjunctival secretion from each eye when the membrane had finally disappeared (Feb. 24th), but with negative results - the staphylococcus epidermidis albus alone heing present. This observation was again repeated on the $27 \mathrm{th}$ with a like result.

\section{STATION HOSPITAL, SIRDARPUR, CENTRAL INDIA.}

A CASE OF ATROPINE POISONING AND A DOUB'TFUL ONE OF STRAMONIUM POISONING.

(Under the care of Surgeon-Lieutenant-Colonel J. Dukr.)

THERE is probably no cuuntry in the world which affords so mush employment and instruction to the toxicologist as India, and we in Great Britain gain considerable aclvantage from a perusal of notes of cases such as the following. It is to be regretted that the time of our medical brethren in the East is so much taken up with practical administrative duties that little is left for the record of clinical observations. Much which we can ill afford to lose should be published but is daily lost to the world owing to want of opportunity on the part of the overworked observer. The duse of atropine in the first case was unusually small in amount to produce such severe symptoms, and owing to the method of administration its effects were exceptionally difficult to overcome.

CAse 1. Atropine poisoning.-On June 21st a Sepoy aged forty years who was otherwise in sound health was admitted for lumbago attributed to a fall from a tree, the patient alighting on his buttocks. On the 25 th five minims of liquor atropiæ P.B. (strength four grains to the ounce) were ordered as an injection into the loin to relieve the pain. The injection was given at 4.30 P.M., and fifteen minutes later he complained of dryness of the throat, giddiness, a feeling of intoxication, and distress. At 5 P.M. the pupils were dilated and the body was trembling. He picked a the bedclothes and was restless, throwing his arms about and moaning. If allowed to rise he wandered about, picking at the walls with his fingers. He was conscious and able to answer questions in a drunken manner. At $7 \mathrm{P}$ M. SurgeonLieutenant-Colonel Duke saw him. He was more or less insensible and restless, tossing about in bed and throwing his arms about wildly, his actions being restrained by two attendants. The noisy, pleasing delirium mentioned by Murrell was present. The pupils were dirated, the pulse was full and strong, and the respiration was thoracic and abdominal. He had apparently a desire to micturate, but was unable to do so. At 7.30 P.M. one-sixth of a grain of pilocarpine was injected subcutaneously; no physiological effects followed. At 8 P.M. the same quantity of pilocarpine was given without any physiological effects, but the delirium seemed to be less. At 9.15 P.M. the patient was quieter, but he was still quite unconscious. The pupils were widely dilated. The pulse was now small, thready, and compressible. At 9.45 P.M. one-sixth of a grain of pilocarpine was again injected ; there were no physiological effects, but the delirium was much lessened. Mustard plasters were applied with bandages to the calves of the legs. At 10.15 P.M. the following enema was given: rum, two ounces; liquor ammoniæ fortior, five minims; and very hot coffee, one pint. At 10.30 P.M. the patient suddenly became conscious and answered questions. He micturated freely. At 12 midnight he was sitting up; he was a little shaky in his movements, but quite rational and answered all questions. $\mathrm{He}$ said that "something had happened to him, but what that something was had gone."

CAST 2 Stramonium poisoning (a doubtful case) -A Sepoy aged thirty-five years was carried to hospital on Sept. 15th. On admission he was insensible. His temperature was $1016^{\circ} \mathrm{F}$. indicating fever; the attendant symptoms were, however, unusual. His decubitus was peculiar; he lay boring his head into the pillow and trying to hide it; he picked at the bedclothes with his fingers and was generally restless. $\mathrm{He}$ tried to get up, but wis unable to stand. His pupils were neither dilated nor contracted. Inquiry showed that on the previous day he had worked with a fatigue party engaged in removing mud from a jiver, and that he was in good health on the evening preceding his attack. He was said to take one pill of opium three times a day. The diagnosis was possibly cerebral effusion. There was no history of poison. A blister was applied to the head, calomel with antifebrine was administered internally, and mustard plasters were applied to the calves. At 7 P.M. the temperature was $102^{\circ}$ At 8 P.M., owing to retention, twelve ounces of urine were drawn off with a catheter. At 9 P.M. his symptoms were serious and much the same; a castor oil enema was ordered. On Sept. 16 th at $8 \mathrm{~A} . \mathrm{M}$. the bowels had been moved three times and there had been romiting once. His behaviour was still most curious. He was more or less delirious and started when the hand was placed on his body. If roused he looked up and then buried his head in the clothes. As these symptoms corresponded to the description of datura poisoning given in the text-books one-sixth of a grain of pilocarpine in ten minims of water was injected. The usual physiological effects followed and the patient became quieter and more conscious. At 6 P.M. the same quantity of pilocarpine was given, after which he was much quieter. On Sept. 17th at $8 \mathrm{~A} \mathrm{M}$. he was conscious and spoke rationally; he walked and took food. He was discharged to duty on the 24th.

Hemarks by Surgeon-Lieutenant-Colonel DukE.-The patient in Case 1 was a confirmed Indian hemp smoker and drinker of twenty years' standing. When the Indian Hemp Commission sat in 1893 he contributed to it the principal written evidence sent from Sirdarpur. Whether this habit renders a man liable to be specially affected by atropine is an open question. My own impression at the time (considering the smallness of the dose and the severity of the symptoms) that the Indian hemp habit had created an idiosyncrasy in this patient is only a conjecture. I can find no mention of it in the text-books. With a view of determining whether the gunja habit hindered the action of pilocarpine, four days after his recovery pilocarpine was again used as follows. On June 29th at 4 P.M. one-sixth of a grain of pilocarpine was injected; at 45 P.M. there were slight forehead 